\title{
The Impact of Talent Management (TM) on Counterproductive Work Behaviors (CWB) in Industrial Companies in Jordan
}

\author{
Maan Hussein Mansour ${ }^{1} \&$ Hazem Khaled Shehadeh ${ }^{2}$ \\ ${ }^{1}$ Department of Business Administration, Zarqa University, Jordan \\ Correspondence: Dr. Maan Hussein Mansour, Department of Business Administration, Zarqa University, Jordan. \\ E-mail: mmansour@zu.edu.jo
}

Received: April 15, 2020

Accepted: May 2, 2020

Online Published: June 8, 2020

doi:10.5539/ijbm.v15n7p96

URL: https://doi.org/10.5539/ijbm.v15n7p96

\begin{abstract}
Counterproductive work Behaviors is certainly causes high economic costs for the organizations, psychological, and social costs as well That is why, it should be well-controlled or the organizations go to a great lost. Therefore many organizations have prioritized talent management to ensure they acquire, develop and retain the right staff. The main objective of this research is to test the impact of talent management on Counterproductive work Behaviors. The questioner was used as a tool to collect information from the study sample in the industrial companies in Jordan. The results showed that there is an impact of talent management, represented in (attract talent, talent retention, talent development and career succession) on Counterproductive work behaviors represented in (sabotage, withdrawal, Deviation in production, Theft, Bribery).
\end{abstract}

Keywords: talent management, counterproductive work behaviors

\section{Introduction}

In recent years, counterproductive work behaviors have received considerable attention from researchers, whereas it has shifted from studying desirable work behaviors to studying undesirable work behaviors.

Increment in deviant behavior in organizations led to many problems and crises, which raised questions about ethics in the work framework and highlighting the need to understand these phenomena in order to prevent and address them. Because of negative effects of these behaviors on organization, society and workers, the researchers' attempts came to understand the factors that affect the likelihood of employees' participation in these behaviors. In addition, the importance of counterproductive works behaviors and their impact on performance of employees and overall performance of organization.

Organizations are more aware than ever that intellectual capital management and talents are critical to strategic success. Managing talented employees is one of the most important sources of success for organizations in a competitive market. Any specialized person who tracks the success of global organizations finds that their success lies not in the use of sophisticated technology and not in diversity of its funding sources, but the secret of its success lies in its possession of exceptional human resources and its good management of them. Therefore, there are always distinguished employees in distinguished organizations.

Attention to talent management in contemporary organizations has emerged as one of sources of strength that can't be imitated, which contributes to ensuring the processes of growth, continuity and development. The task of talent discovery grows to be one of the main tasks of human resources management when performing its job, which is recruiting, selecting, training, refining, developing and maintaining talents.

Due to importance of talent management and its role in influencing on performance and behaviors of employees, especially counterproductive behaviors, this study seeks to investigate the impact of talent management on counterproductive work Behaviors in industrial companies in Jordan.

\section{Importance of the Study}

This study covers two topics that are considered important and modern in the literature of business administration in general, human resources management and organizational behavior in particular, hence the scientific and academic importance of this study comes from the absence of such kind of studies in Arab library.

Also, This study follows (Mensah, 2014) recommendation, which recommended that several research studies 
should be conducted to demonstrate the impact of talent management on the different dimensions of organizational performance, including productivity science behaviors. Therefore the importance this study comes from its attempt to discover and identify the factors most capable of minimizing these anti-productivity behaviors in business organizations.

\section{Study Problem}

Through the researcher's review of the literature discussed in the areas of organizational behavior and human resources management, it has been concluded that the interest of academics researchers has shifted from just studying the positive behaviors of employees within their organizations such as organizational commitment and organizational engagement... etc, to study negative behaviors in a place of work such as robbery, violence and vandalism Especially in the last ten years.

The current study is an attempt in this direction, as it seeks to determine the impact of talents' management strategies on counterproductive work behaviors. Review of literature indicates the existence of some foreign studies that examined, for example, human resource management practices and their impact on counterproductive work behaviors. In addition, one study examined developing talents and its influence on counter productive work behaviors. Some studies sought at providing a conceptual framework demonstrating mechanisms by which talents management can lead different dimensions of functional performance, which assumed that talents' management strategies will be connected in a negative form with counterproductive work behaviors. At the same time, there is no single Arab study examined the relationship between talents and counterproductive work behaviors.

\section{Study Hypotheses}

To achieve the objectives of the research, this research seeks to test the following hypotheses:

H1: There is no statistically significant impact of talent management practices on Counterproductive Work Behaviors in industrial companies in Jordan? The following sub-hypotheses are derived:

H1.1: There is no statistically significant impact of the practices of talent management on sabotage in industrial companies in Jordan

H1.2: There is no statistically significant impact of talent management practices on withdrawal in industrial companies in Jordan

H1.3: There is no statistically significant impact of talent management practices on the deviation in production in industrial companies in Jordan

H1.4: There is no statistically significant impact of talent management practices on theft in industrial companies in Jordan

H1.5 There is no statistically significant impact of talent management practices on bribery in industrial companies in Jordan

\section{Literature Review}

\subsection{Talent Management}

In this component, we will focus on the approach of talents' management, which has achieved excellence and success in business world because of its great role in attracting, developing and retaining talents for the organization. Through reviewing the connected literature of talents' management, we find that researchers differ on conceptual limits of talents' management, some of them dealt with it as an attitude like( Blass, 2009) and (Yarnall, 2011), and others as a thought (Aston \& Morton, 2005).

It is noteworthy that key and pivotal point of talents' management was in the late 1990s, particularly in 1998, when McKinsey and America's largest companies for management consultations (War for Talents), used the expression of intense competition among organizations for having and recruiting talents to work in the organizations. At the same time, some studies have confirmed that talents' management has become a basic topic in human resources management literature, in which, the environment is characterized by it is a competitive and changing environment (Zhang \& Bright, 2012).

Talents' management is defined as a strategic view and a holistic entry to both the human resource and business planning, or it can be considered a new way of organizational effectiveness. Consequently, improving performance and potentials of talented individuals through which measurable difference can be made in the organization now and in future. Thus, talents' management is not just a word seeks to find and develop the talented (Cunningham, 2007), rather than it requires an organized vision that focuses on dynamic interaction 
among many tasks and processes within business organizations, as well as a proactive and continuous method (Schweyer, 2004).

According to (Collings \& Mellahi, 2009), talents' management has been defined as a set of activities and processes that involve a systematic and precise identification of main functions within the organization that contribute significantly in achieving sustainable competitive advantage of the organization. This includes attracting qualified employees and integrating them as well as maintaining current employees for improving the talents within the organization to achieve the organization's current and future objectives.

As for (Yllner, 2013), he believes that talents' management includes programs that may have many similarities with human resources management, but the content of talents' management is much deeper not only as it aims to manage these talents but also to building a distinct career path for them, ensuring of maintaining them and buildingnew future roles for them. In another context (Uren\& Samuel, 2007) noted that talents' management reflects a series of rational steps represented in identifying, attracting, disseminating and developing the talent. While (Sloan et al. (2003) and (Rodriguez, 2010) agreed that talents' management is managing comprehensive leadership of talent strategically, with the aim of placing the right person in the right place at the right time.

(Horvathova,2009) reports that effective work with talented employees is based on a strategy for talents' management derived from overall strategy of organization, which ensures that current talented and qualified employees within the organization contribute in achieving current and future needs of organization. This procedure may be called talent's fund, which consists of a group of talented people who are prepared to take on responsibilities of various talents and abilities. The Talents' Fund, which is developed depends on a number of executive positions and on organization's ability to innovate and develop. For example, in medium organizations, there may be one fund, but in large organizations, it may differ in terms of possessing two talents' funds, one for senior management levels and the other for middle management levels. In addition, often the number of talents' funds reflects the degree of organization within these organizations (Beheshtifar \& Moghadam, 2011).

There is almost agreement among researchers on the significance of talents' management in organization and its impact on other some organizational variables such as entrepreneurship (Shirkhan\&Nazari, 2014), job engagement, job satisfaction, organizational loyalty (Sajadi et al., 2014), reducing work pressure(Chatroodi \& Sanjar, 2014), reducing intension of leaving work (Rana \& Abbasi, 201), organizational creativitiy (Khoram and Abbas, 2013), employee retention (Tiwar \& Shrivastava, 2013), functional and organizational integration (Oladapo 2014), organizational growth, high performance, competitive advantage (Van Zyl et al., 2017) and assisting in managers' selection process (Katarzyna et al., 2015) which indicates that talents' management is a very important subject due to its positive impact on above organizational variables.

As for talents' management dimensions, there is almost agreement among researchers (Serbana \& Andanuta, 2014-Beheshtifar et al., 2012-MatheAnca 2013-Landwehr 2015-2016) on dimensions and processes of talents' management, which are (talents' attraction, talents' development, talents' retention, career progression) as the following:

\subsubsection{Talent Attraction}

Academic researches examining talents' attraction can be categorized into two areas: First, Talents' planning and distribution: The role of talents' planning is identifying future talents' needs that are very important at all organization's levels. Focus is made on talents' quality (knowledge, skills, abilities and personality traits) which will be used in many locations. The goal of talents' planning is to achieve an ideal level of talent placement, which will eventually put the right talent in the right place at the right time with needed rewards and incentives at all locations and levels of organization (Guthridge et al., 2008).and The second area is human resources' reputation, where organizations focus on characteristics that make them more attractive to a group of potential applicants, especially those who are talented. Many organizations focus on improving their human resource reputation to attract human talents. The reputation of human resources is based on impression generated by applicants through the image that the organization reflects as an employment authority that can be positive, neutral or negative. It is important that organizations deal with applicants as if they are clients to reflect their respect for their employees as well, and they must identify competitors' employers, analyze their situations as much as possible and focus on organizational characteristics that interest particular candidates (Cadin \& Pigeyre, 1999).

\subsubsection{Training and Development}

Developing and improving strategy of talents' base, which is based on training talented people through a range of tasks that depends on assessing abilities and potentials of talents' base members, and then look for deficiencies in 
the talents' matrix elements, after that developing a training program to cover these shortcomings as well as up raising training results. Davis et al. (2007, p. 267) reports that there are two types of development for individuals, namely, first, developing knowledge, which means providing employee with technical and professional skills in order to perform a certain and specific role. Here the idea is to prepare individual for the role that he will be responsible for in the future. This is before promoting him or assigning more responsibilities for him, so we can avoid the loss of confidence that may occur because of an employee's promotion while he is disqualified or unprepared for the new role that he will occupy. It must be emphasized that the degree of diversity of individuals working within business organizations is an important factor for developing individuals' capabilities, potentials and enriching ideas (Stevens, 2010) within organizations.

Secondly, developing personal skills, namely developing characteristics, qualities and skills that talented employee will be require them during his professional life such as focusing skills, working under pressure, communication, innovation, creativity and others. Thus, here stems the query whether this type of characteristics and skills is inherent qualities in the person or that it can be developed through training. Our opinion is that each person has many inherent qualities in his personality or has been developed, and here it can be said that these qualities can be developed and reinforced by training, provided they are available in individual's personality where they can not be created from nothing.

\subsubsection{Talent Retention}

In order for organizations to be successful, they need to invest more in retaining talented employees because not retaining talented employees, leads to higher talents' turnover that is detrimental to the organization's productivity, as well as leads to financial costs to re-attract talents. The most important elements, which are considered as are tools that help organizations to retain talents are: competitive compensation package, organizational culture supporting talents, professional and personal growth opportunities, challenging work, balance between life and work (Armstrong, 2006).

\subsubsection{Succession Planning}

Business organizations focus in their upgrading and developmental programs on developing leadership skills as an important and main tool in retaining talents. The critical element in development leadership skills is planning for job progression, which focuses on identifying and developing talents for important leadership positions and on its importance in retaining talents in many times. This happens as a belief that organizations lacking progression planning for the jobs are more at risk of leakage and loss of talents (Cohn et al., 2005).

\subsection{Counterproductive Work Behaviors}

Authors and researchers hold opposing views about the concept of counterproductive work behaviors, where they used many terms to indicate these behaviors. (Robinson and Bennett, 1995) identified the counterproductive work behaviors through the term of workplace deviation, which indicates to a voluntary behavior that violates main regulations structures and it threatens the welfare of the organization and its members. Giacalone and Greenberg (1997) report these behaviors through the term anti-social behavior, which is defined as a behavior that brings damage or aims to harm the organization and its employees or organizational stakeholders, including aggression, discrimination, theft, dealing violently, vandalism, harassment, lying and revenge.

Vardi and Wiener (1996) called these behaviors organizational misconduct, which means intentional action by organization's members that violates basic organizational structures or societal regulations. (Spector \& Fox, 2002) dealt with counterproductive work behaviors as the behaviors that harm organization either directly by negatively affecting its functions or properties, or by harming its employees in a way that reduces their effectiveness.

Barney et al. (2003) state that these behaviors are voluntary organizational behaviors that affect on job performance.(Penney \& Spector, 2005) defined them as behaviors that harm the organization and its members, including sabotage, verbal abuse, reducing efforts, lying, refusal to cooperate, and physical attacks. In addition, (Kelloway et al., 2010) defined counterproductive work behaviors as a form of protest by organization's members to express their resentment and dissatisfaction within the organization, in an attempt to resolve injustice that falls upon them.

Liu Zhen and XU Meixin, (2012) stated that the organization has the potential to achieve significant performance from work if it is interested in discovering counterproductive work behaviors and treating them, but they are a good source of profit.

(Retail Research, 2010) pointed out that almost all large and small organizations exposed to potential damages by counterproductive work behaviors. For example, employee theft may account for approximately $35 \%$ of 
organization's inventory shrinkage, an average of $1.4 \%$ of its total revenues. These estimates associated with actual damage of counterproductive work behaviors may be much higher than because of relatively low detection rates of them.

Hakstian and Tweed, (2002) report that the study of counterproductive work behaviors has great importance because counterproductive work behaviors have intrinsic impact on organizational effectiveness. However, the three reasons that explain why we study counterproductive work behaviors: First, major ramifications caused by counterproductive work behaviors in terms organizations' financial costs. Second, there is a large proportion of individuals participate in counterproductive work behaviors. Third, change in work nature led to search for counterproductive work behaviors. It is also important to study all parties regarding counterproductive work behaviors because work is done in a collective framework, and impact of counterproductive work behaviors is not limited to the individual and the organization, but there are many parties affected by these behaviors.

\subsection{Talents Management and Counterproductive Work Behaviors}

In recent years, counterproductive work behaviors have received substantial attention from many researchers because of negative effects that these behaviors cause to the organization, workers and society. Liu Zhen and XU Meixin, (2012) assured that the organization has the potential to gain large performance from work if it is interested in discovering and treating counterproductive work behaviors, but is a new source of profit.

Shamsudin et al. (2011) in their study of impact of human resources management on counterproductive work behaviors in a group of industrial firms in Malaysia, they noted that weak progression planning processes and internal promotion opportunities for employees help in increasing counter productive work behaviors within organization.

Rishipal and Awasthi (2015) pointed out that training and development of talented individuals contributes to the manifestation and reduction of negative consequences of counterproductive work behaviors at individual and organization levels.

Mensah (2014) study aimed to provide a conceptual framework that explains mechanisms by which talent management can lead different dimensions of functional performance. Despite the lack of empirical evidence connecting talents' management and functional performance, it can be assumed that talents' management strategies will negatively connected to counterproductive work behaviors and this is due to two reasons: talent management emphasizes identifying talented people and working on managing them well, hence their performance is likely to be positive. Second, most employees will not take part in behaviors that harms their organizations. The study reached to a result that is talents' management positively is connected to both task performance, contextual performance and adaptive performance. In addition, it is inversely associated with counterproductive performance, and this relationship mediates outputs of talents' management.

The researchers have studied several studies, which have also confirmed negative impact of counterproductive work behaviors on organization's efficiency and effectiveness, such as increasing turnover of employees, decreasing functional performance, influencing on attraction's operations, employees' retention and decreasing of quality of services provided to customers. In addition, distorting organization's image before customers and society, this sometimes leads to collapse of the whole organization (Liu Zhen \& Xu Meixin, 2012; Hakstian \& Tweed, 2002; Catabulga \& Burtaverde, 2012).

\section{Proposed Study Model}

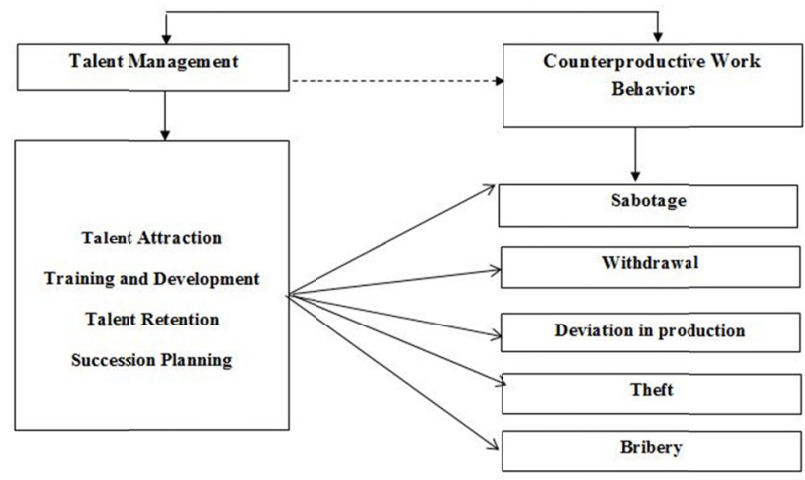

This study aims to recognize the "The Impact of Talent Management on Counterproductive Work Behaviors . 
The study includes four independent variables (talent attraction, training and development ,talent retention, succession planning) as these independent variables measured the talent management. While the dependent variables of the good Counterproductive Work Behaviors include five dimensions as well (sabotage, withdrawal, deviation in production, theft, bribery). It is an empirical study which used a descriptive and analytical approaches. The researcher designed one questionnaire instrument for industrial companies. The questionnaire was designed to collect and analyze the data to get the information needed in this study for empirical purposes.

\section{Research Population and Sample}

The research population in this research is all managerial staffs working in industrial public sharing companies in Jordan. Based on Securities Depository Center of Jordan ( 58) companies exist and targeting the research. The population size about 160 managerial staff work in the companies. Regarding to Sekaran table (Sekaran, 2010) the representatives sample shouldn't be less than 108. The researcher distributed 160 questionnaires for the population, the returned and valid to analyze questionnaires were 115 respondents the sample size. The researcher depended on purposive samples for distributing the question questionnaire.

\subsection{Validity and Reliability}

\subsubsection{Face Validity}

Face validity, also called logical validity, is a simple form of validity where you apply a superficial and subjective assessment of whether your study or test measures what it is supposed to measure (Gay \& Airasian, 2000). To measure the questionnaire's statements for clarity and providing a coherent study questionnaire, a macro review to all the study constructs was performed by academic reviewers from Jordanian universities specialized in business management and marketing management.

\subsubsection{Reliability}

Reliability is the degree to which a test consistently measures whatever it is measuring and the reliability coefficient indicates the consistency of the score produced (Gay and Airasian, 2000). Reliability of the scale is that an instrument provides similar results every time it is administrated to the same sample at different times.

The reliability analysis applied to the level of Cronbach Alpha $(\alpha)$ is the criteria of internal consistency which was at a minimum acceptable level (Cronbach's Alpha $\geq 0.70$ ) suggested by (Sekaran \& Bougie 2013). Table (1) shows the reliability of the independent and dependent variables (Cronbach's Alpha).

Table 1. Cronbach's Alpha

\begin{tabular}{lll}
\hline Number & Variables & Cronbach's Alpha \\
\hline 1 & Talent attraction & 0.876 \\
2 & Training and Development & 0.804 \\
3 & Talent Retention & 0.822 \\
4 & Succession Planning & 0.728 \\
5 & Sabotage & 0.904 \\
6 & Withdrawal Division in production & 0.872 \\
7 & Theft & 0.844 \\
8 & Bribery & 0.798 \\
9 & All items & 0.953 \\
\hline
\end{tabular}

From the table 1, we can see that all the study variables' reliability Cronbach's alpha values are more than (0.7). The highest Cronbach's alpha value (0.904) belongs to the "Sabotage" variable, while the lowest $(0.728)$ belongs to the "Succession Planning' variable. All items' Coefficient Cronbach's Alpha is (0.953), therefore, the study results can be accepted according to (Sekaran \& Bougie 2013).

\subsubsection{Variance Inflation Factor (VIF)}

The variance inflation factor $(V I F)$ quantifies the extent of correlation between one predictor and the other predictors in a model. It is used for diagnosing multicollinearity. Higher values signify that it is difficult to impossible to assess accurately the contribution of predictors to a model.

According to Hair, Ringle, and Sarstedt (2011) VIF 5 or higher, it indicates a potential issue with multicollinearity problem. Therefore, in this study, there is no multicollinearity problem because there the value of VIF is below than 5. See (Table 2). 
Table 2. Variance inflation

\begin{tabular}{llc}
\hline Variables & VIF & Tolerance \\
\hline Talent attraction & 1.103 & 0.122 \\
Training and Development & 1.285 & 0.249 \\
Talent Retention & 1.203 & 0.374 \\
Succession Planning & 2.402 & 0.503 \\
\hline
\end{tabular}

\section{Hypotheses Testing}

The linear regression procedure examines the impact of a set of independent variables on the dependent variable. In these study hypotheses testing is based on Multiples linear regression.

$\mathrm{H}_{1}$ : There is No statistically significant impact of talent management practices on Counterproductive Work Behaviors in industrial companies in Jordan at the significance level $(\alpha \leq 0.05)$.

Multiple linear regression was used to test $\mathrm{t}$ main hypothesis at the significance level $(\alpha \leq 0.05)$.

Table 3. Results of multiple regressions of the main hypothesis

\begin{tabular}{|c|c|c|c|c|c|c|c|c|}
\hline Dependent Variable & $\mathbf{R}$ & $\mathbf{R}^{2}$ & $\mathbf{F}$ & SIG & Independent Variable & B & $\mathbf{T}$ & Sig \\
\hline \multirow{4}{*}{ Counterproductive work Behaviors } & \multirow{4}{*}{0.905} & \multirow{4}{*}{0.819} & \multirow{4}{*}{412.864} & \multirow{4}{*}{0.000} & Talent attraction & 0.333 & 5.350 & 0.000 \\
\hline & & & & & Training and Development & 0.179 & 3.061 & 0.010 \\
\hline & & & & & Talent Retention & 0.558 & 8.218 & 0.000 \\
\hline & & & & & Succession Planning & 0.286 & 4.089 & 0.000 \\
\hline
\end{tabular}

Table 3 shows the study dependent variable (Counterproductive work Behaviors) and the set of the independent variables (talent attraction, training and development, talent retention, succession planning), are significant because F significant was $(0.000)$ which is less than $(0.05)$ and the calculated $F$ value is $(412.864)$, which is more than F value table (2.42), therefore, we accept the hypothesis which states that:

There is statistically significant impact of talent management practices on Counterproductive Work Behaviors in industrial companies in Jordan at the significance level $(\alpha \leq 0.05)$.

The relationship between the dependent and independent variables is strong and positive. It is more than $(0.5)$ (Cohen, 1988), $\mathrm{R}=0.905$. Also, the $\mathrm{R}^{2}=0.819$, which means that the independent variables contribution impact the dependent variable in a percentage of $81.9 \%$.

Since the values of the calculated $\mathbf{t}$ values of the variables (talent attraction 5.350, training and development 3.061 ,talent retention 8. 218, succession planning 4.089), are more than the $\mathbf{t}$ value table (1.96), it means that there is statically significant impact on the dependent variables.

$\mathrm{H}_{1.1}$ : There is no statistically significant impact of the practices of talent management on sabotage in industrial companies in Jordan at the significance level $(\alpha \leq 0.05)$.

Table 4. Results of multiple regressions of the first sub hypothesis

\begin{tabular}{|c|c|c|c|c|c|c|c|c|}
\hline Dependent Variable & $\mathbf{R}$ & $\mathbf{R}^{2}$ & $\mathbf{F}$ & SIG & Independent Variable & B & $\mathbf{T}$ & Sig \\
\hline \multirow{4}{*}{ Sabotage } & \multirow{4}{*}{0.912} & \multirow{4}{*}{0.832} & \multirow{4}{*}{341.504} & \multirow{4}{*}{0.000} & Talent attraction & 0.272 & 4.252 & 0.000 \\
\hline & & & & & Training and Development & 0.248 & 3.922 & 0.001 \\
\hline & & & & & Talent Retention & 0.443 & 7.845 & 0.000 \\
\hline & & & & & Succession Planning & 0.322 & 5.321 & 0.000 \\
\hline
\end{tabular}

Table 4 shows the study dependent variable (Sabotage) and the set of the independent variables (talent attraction, training and development ,talent retention, succession planning), are significant because F significant was (0.000) which is less than (0.05) and the calculated F value is (341.504), which is more than F value table (2.42), therefore, we accept the hypothesis which states that:

There is statistically significant impact of talent management practices on Sabotage in industrial companies in Jordan at the significance level $(\alpha \leq 0.05)$.

The relationship between the dependent and independent variables is strong and positive. It is more than $(0.5)$ (Cohen, 1988), $\mathrm{R}=0.912$. Also, the $\mathrm{R}^{2}=0.832$, which means that the independent variables contribution impact 
the dependent variable in a percentage of $83.2 \%$.

Since the values of the calculated $\mathbf{t}$ values of the variables (talent attraction 4.252, training and development 3.922, talent retention 7.845, succession planning 5.321), are more than the $\mathbf{t}$ value table (1.96), it means that there is statically significant impact on the dependent variables.

$\mathrm{H}_{1.2}$ : There is no statistically significant impact of the practices of talent management on withdrawal in industrial companies in Jordan at the significance level $(\alpha \leq 0.05)$.

Table 5. Results of multiple regressions of the second sub hypothesis

\begin{tabular}{|c|c|c|c|c|c|c|c|c|}
\hline Dependent Variable & $\mathbf{R}$ & $\mathbf{R}^{2}$ & $\mathbf{F}$ & SIG & Independent Variable & B & $\mathbf{T}$ & Sig \\
\hline \multirow{4}{*}{ withdrawal } & \multirow{4}{*}{0.892} & \multirow{4}{*}{0.795} & \multirow{4}{*}{288.577} & \multirow{4}{*}{0.000} & Talent attraction & 0.304 & 4.209 & 0.00 \\
\hline & & & & & Training and Development & 0.257 & 3.019 & 0.001 \\
\hline & & & & & Talent Retention & 0.381 & 5.325 & 0.000 \\
\hline & & & & & Succession Planning & 0.189 & 2.587 & 0.003 \\
\hline
\end{tabular}

Table 5 shows the study dependent variable (withdrawal) and the set of the independent variables (talent attraction, training and development, talent retention, succession planning), are significant because $\mathrm{F}$ significant was $(0.000)$ which is less than $(0.05)$ and the calculated $F$ value is $(288.577)$, which is more than $F$ value table (2.42), therefore, we accept the hypothesis which states that:

There is statistically significant impact of talent management practices on withdrawal in industrial companies in Jordan at the significance level $(\alpha \leq 0.05)$.

The relationship between the dependent and independent variables is strong and positive. It is more than $(0.5)$ (Cohen, 1988), $\mathrm{R}=0.892$. Also, the $\mathrm{R}^{2}=0.795$, which means that the independent variables contribution impact the dependent variable in a percentage of $79.5 \%$.

Since the values of the calculated $\mathbf{t}$ values of the variables (talent attraction 4.209, training and development 3.019 , talent retention 5.325, succession planning 2.587), are more than the $\mathbf{t}$ value table (1.96), it means that there is statically significant impact on the dependent variables.

$\mathrm{H}_{1.3}$ : There is no statistically significant impact of the practices of talent management on Deviation in production in industrial companies in Jordan at the significance level $(\alpha \leq 0.05)$.

Table 6. Results of multiple regressions of the third sub hypothesis

\begin{tabular}{lllllllll}
\hline Dependent Variable & $\mathbf{R}$ & $\mathbf{R}^{2}$ & $\mathbf{F}$ & SIG & Independent Variable & $\mathbf{B}$ & $\mathbf{T}$ & Sig \\
\hline & & & & & Talent attraction & 0.330 & 4.416 & 0.000 \\
Deviation in production & \multirow{2}{*}{0.838} & \multirow{2}{*}{0.702} & \multirow{2}{*}{217.653} & \multirow{2}{*}{0.000} & Training and Development & 0.249 & 3.56 & 0.001 \\
& & & & & Talent Retention & 0.506 & 6.840 & 0.000 \\
& & & & & Succession Planning & 0.289 & 3.325 & 0.002 \\
\hline
\end{tabular}

Table 6 shows the study dependent variable (Deviation in production) and the set of the independent variables (talent attraction, training and development, talent retention, succession planning), are significant because $\mathrm{F}$ significant was (0.000) which is less than (0.05) and the calculated $\mathrm{F}$ value is (217.653), which is more than $\mathrm{F}$ value table (2.42), therefore, we accept the hypothesis which states that: There is statistically significant impact of talent management practices on Deviation in production in industrial companies in Jordan at the significance level $(\alpha \leq 0.05)$.

The relationship between the dependent and independent variables is strong and positive. It is more than $(0.5)$ (Cohen, 1988), $\mathrm{R}=0.838$. Also, the $\mathrm{R}^{2}=0.702$, which means that the independent variables contribution impact the dependent variable in a percentage of $70.2 \%$.

Since the values of the calculated $\mathbf{t}$ values of the variables (talent attraction 4.416, training and development 3.560 , talent retention 6.840, succession planning 3.325), are more than the $\mathbf{t}$ value table (1.96), it means that there is statically significant impact on the dependent variables.

$\mathrm{H}_{1.4}$ : There is no statistically significant impact of the practices of talent management on Theft in industrial companies in Jordan at the significance level $(\alpha \leq 0.05)$. 
Table 7. Results of multiple regressions of the forth sub hypothesis

\begin{tabular}{|c|c|c|c|c|c|c|c|c|}
\hline Dependent Variable & $\mathrm{R}$ & $\mathrm{R}^{2}$ & $\mathrm{~F}$ & SIG & Independent Variable & $\mathrm{B}$ & $\mathrm{T}$ & Sig \\
\hline \multirow{4}{*}{ Theft } & \multirow{4}{*}{0.872} & \multirow{4}{*}{0.757} & \multirow{4}{*}{74.184} & \multirow{4}{*}{0.000} & Talent attraction & 0.289 & 2.938 & 0.006 \\
\hline & & & & & Training and Development & 0.274 & 2.863 & 0.001 \\
\hline & & & & & Talent Retention & 0.326 & 3.351 & 0.000 \\
\hline & & & & & Succession Planning & 0.284 & 3.281 & 0.001 \\
\hline
\end{tabular}

Table 7 shows the study dependent variable (Theft) and the set of the independent variables (talent attraction, training and development ,talent retention, succession planning), are significant because F significant was $(0.000)$ which is less than $(0.05)$ and the calculated $\mathrm{F}$ value is (74.184), which is more than $\mathrm{F}$ value table (2.42), therefore, we accept the hypothesis which states that: There is statistically significant impact of talent management practices on Theft in industrial companies in Jordan at the significance level $(\alpha \leq 0.05)$.

The relationship between the dependent and independent variables is strong and positive. It is more than $(0.5)$ (Cohen, 1988), $\mathrm{R}=0.872$ Also, the $\mathrm{R}^{2}=0.757$, which means that the independent variables contribution impact the dependent variable in a percentage of $75.7 \%$.

Since the values of the calculated $\mathbf{t}$ values of the variables (talent attraction 2.938, training and development 2.863, talent retention 3.351, succession planning 3.281), are more than the $\mathbf{t}$ value table (1.96), it means that there is statically significant impact on the dependent variables.

$\mathrm{H}_{1.5}$ : There is no statistically significant impact of the practices of talent management on Bribery in industrial companies in Jordan at the significance level $(\alpha \leq 0.05)$.

Table 8. Results of multiple regressions of the fifth sub hypothesis

\begin{tabular}{|c|c|c|c|c|c|c|c|c|}
\hline Dependent Variable & $\mathbf{R}$ & $\mathbf{R}^{2}$ & $\mathbf{F}$ & SIG & Independent Variable & B & $\mathbf{T}$ & Sig \\
\hline \multirow{4}{*}{ Bribery } & \multirow{4}{*}{0.891} & \multirow{4}{*}{0.794} & \multirow{4}{*}{185.692} & \multirow{4}{*}{0.000} & Talent attraction & 0.262 & 2.963 & 0.003 \\
\hline & & & & & Training and Development & 0.193 & 2.213 & 0.001 \\
\hline & & & & & Talent Retention & 0.291 & 3.424 & 0.000 \\
\hline & & & & & Succession Planning & 0.289 & 3.836 & 0.0001 \\
\hline
\end{tabular}

Table 8 shows the study dependent variable (Bribery) and the set of the independent variables (talent attraction, training and development, talent retention, succession planning), are significant because F significant was $(0.000)$ which is less than (0.05) and the calculated $\mathrm{F}$ value is (185.692), which is more than $\mathrm{F}$ value table (2.42), therefore, we accept the hypothesis which states that:

There is statistically significant impact of talent management practices on Bribery in industrial companies in Jordan at the significance level $(\alpha \leq 0.05)$.

The relationship between the dependent and independent variables is strong and positive. It is more than $(0.5)$ (Cohen, 1988), $\mathrm{R}=0.891$ Also, the $\mathrm{R}^{2}=0.794$, which means that the independent variables contribution impact the dependent variable in a percentage of $79.4 \%$.

Since the values of the calculated $\mathbf{t}$ values of the variables (talent attraction 2.963, training and development 2.213 ,talent retention 3.424, succession planning 3.836), are more than the $\mathbf{t}$ value table (1.96), it means that there is statically significant impact on the dependent variables.

\section{Results of Study}

- There is statistical significant impact for talent management on counterproductive work behavior in industrial companies in Jordan. In addition the talent management has explained counterproductive work behavior about $(81.9 \%)$. Also the talent management has strong relation with counterproductive work behavior.

- There is statistical significant impact for talent management on sabotage is among counterproductive work behavior dimensions in industrial companies in Jordan. In addition the talent management has explained sabotage about (83.2\%). Also the talent management has strong relation with sabotage.

- There is statistical significant impact for talent management on withdrawal is among counterproductive work behavior dimensions in industrial companies in Jordan. In addition the talent management has explained withdrawal about (79.5\%). Also the talent management has strong relation with withdrawal.

- There is statistical significant impact for talent management on Deviation in production is among counterproductive work behavior dimensions in industrial companies in Jordan. In addition the talent 
management has explained Deviation in production about (70.2\%). Also the talent management has strong relation with Deviation in production.

- There is statistical significant impact for talent management on Theft is among counterproductive work behavior dimensions in industrial companies in Jordan. In addition the talent management has explained Theft about (75.7\%). Also the talent management has strong relation with Theft.

- There is statistical significant impact for talent management on Bribery is among counterproductive work behavior dimensions in industrial companies in Jordan. In addition the talent management has explained Theft about (79.4\%). Also the talent management has strong relation with Bribery.

\section{Conclusions and Recommendations}

This research deals with two topics that are important and recent topics in the field of organizational behavior in general and the science of human resources management in particular, talent management and counterproductive work behaviors. The study sought to demonstrate the impact of talent management practices (attract talent, talent retention, talent development and career succession) on counter productive work behaviors(sabotage, withdrawal, Deviation in production, Theft, Bribery ) and The results showed that there is an effect (inverse relationship) of the aforementioned talent management practices on the counter productive work behaviors in the Industrial companies in Jordan. Therefore, the researchers hope that the results of this research will help officials in industrial companies to counter productive work behaviors and work to address and identify the most important talent management practices that work to reduce counter productive work behaviors. A number of recommendations can be suggested through the findings: first of all Talent management practices should be improved at all managerial levels and better linking talent management activities to the strategic objectives of the organization. And Work on the fairness of the performance appraisal according to transparent and objective bases and in order to contribute to the development of the career path of employees and work as well to increase the degree of employee participation in decision-making processes. Finally, It is also necessary to focus on developing a culture of organization that supports talent and thereby enhance organizational commitment and thereby reduce counter productivity work behaviors.

\section{References}

Anca-Letitia, C. (2013). Talent management Practices for sustainable enterprise. Conference Proceeding, Managerial Challenges of the Contemporary Society, 5.

Armstrong, M. (2006). A Handbook of Human Resource Management Practice (10th ed.). London: Kogan Page Publishing.

Aston, C., \& Morton, L. (2005). Managing talent for competitive advantage. Strategic HR Review, 4(5), 28-31. https://doi.org/10.1108/14754390580000819

Bashir, S., Nasir, M., \& Qayyum, S. (2012). Dimensionality of Counterproductive Work Behaviors in Public Sector Organizations of Pakistan. Public Organiz Rev, 12, 357-366. https://doi.org/10.1007/s11115-012-0177-8

Beheshtifar, M., \& Moghadam, M. (2011). Talent Management: A Complementary Process for Succession Planning. Life Science Journal, 8(4), 474-477.

Beheshtifar, M., Nasab, H., \& Moghadam, N. (2012). Effective talent management: A vital Strategy to Organizational Success. International Journal of Academic Research in Business and Social Sciences, 2(12), 227-234.

Blass, E. (2009). Talent Management: Cases and Commentary: Great Britain. Chippenham and East bourne, 19, https://doi.org/10.1057/9780230233522

Catabulga, C., \& Burtăverde, V. (2012). Correlative study between mental health, physical health, pro-organizational behaviors, and counterproductive behaviors in a telephonic company from Chişinău. Romanian Journal of Experimental Applied Psychology, 3(3), 22-28.

Cohn, J. M., Khurana, R., \& Reeves, L. (2005). Growing Talent as if Your Business Depended on It. Harvard Business Review, (83), 62-70.

Collings, G., \& Mellahi, D. (2009). Strategic talent management: A review and research agenda. Human Resource Management Review, 19, 304-313. https://doi.org/10.1016/j.hrmr.2009.04.001

Cunningham, I. (2007). Talent management making it real, development and learning in organizations. https://doi.org/10.1108/14777280710727307 
Davies, T., Maggie, C., \& Neil, F. (2007). Talent assessment, a new strategy for talent management.

Forough, M., Chatroodi, M., \& Salajegheh, S. (2014). Studying The Relationship Between Talent Management With Job Stress in Municipaliy, Kerman. Kuwait Chapter of Arabian Journal of Business and Management Review, 3(9), 236. https://doi.org/10.12816/0018345

Giacalone, R. A., \& Greenberg, J. (1997). Antisocial behavior in organizations. Thousand Oaks, CA: Sage.

Guthridge, M., Komm, A., \& Lawson, E. (2008). Making talent a strategic priority. McKinsey Quarterly, 48(1).

Hakstian, A., Farrell, S., \& Tweed, R. (2002). The assessment of counter-production tendencies by means of the California Psychological Inventory. International Journal of Selection and Assessment, 10, 58-86. https://doi.org/10.1111/1468-2389.00194

Horvathova, P. (2009). Enterprise: Performance and Business Processes, Perspectives of Innovations. Economics \& Business, (3), 77.

Katarzyna, S., Copp, T., \& AndLis, M. (2015). Talent Management in the Development of Chinese Companies' Competitiveness.

Kelloway, E. K., Francis, P. M., \& Cameron, J. E. (2010). Counterproductive work behavior as protest. Human Resource Management Review, 20, 18-25. https://doi.org/10.1016/j.hrmr.2009.03.014

Khoram, L. A., \& Samadi, A. (2013). Relationship of Talent Management and Organizational Creativity in Maskan Bank of Hamadan Middle-East. Journal of Scientific Research, 18(5), 728-731.

Landwehr, J. (2016). The Use of Talent Management Instruments and Procedures in Germany: A Broad Explorative Study of Effectiveness and Success Factors. Journal of Human Resource Management, 4(6), 77-99. https://doi.org/10.11648/j.jhrm.20160406.12

Liu, Z., \& Xu, M. X. (2012). Preliminary Exploring the Influence of Person-Organization Fit on Counterproductive Work Behavior. International Journal Business and Management, 4(2), 133-139.

Mensah, J. (2015). A coalesced framework of talent management and employee performance: For further research and practice. International Journal of Productivity and Performance Management, 64(4), 544-566. https://doi.org/10.1108/IJPPM-07-2014-0100

Oladapo, V. (2014). The impact of talent management on retention. Journal of Business Studies Quarterly, 5(3).

Penney, L. M., \& Spector, P. E. (2005). Job stress, incivility, and counterproductive work behavior (CWB): the moderating role of negative affectivity. Journal of Organizational Behavior, 26, 777-796. https://doi.org/10.1002/job.336

Rana, A. H., \& Abbasi, A. S. (2013). Impact of Talent Management and on Employee Turnover Intention Organizational Efficiency - A Case of Telecommuting Sector of Pakistan. Sci. Int (Lahore), 25(3), 655-660.

Rishipal, \& Awasthi, S. (2015). Employee Development : A Tool To Check Counter Productive Work Behaviour. International Journal of Research in Management, Economics \& Commerce, 5(12).

Robinson, S., \& Bennett, R. (1995). A typology of deviant workplace behaviors: a Multidimensional scaling study. Academy of Management Journal, 38(2), 555-572. https://doi.org/10.2307/256693

Rodríguez, B. (2010). Talents, The key for successful organizations, Master Thesis, Linnaeus University, school of business and economics, Kalmar, Sweden.

Schweyer, A. (2004). Talent Management Systems: Best Practices in Technology Solutions for Recruitment. Retention and Workforce Planning.

Serbana, A., \& Andanuta, M. (2014). Talent Competitiveness and Competitiveness through Talent. 21st International Economic Conference, Procedia Economics and Finance, 16, 506-511. https://doi.org/10.1016/S2212-5671(14)00831-4

Shamsudin, F., Subramaniam, C., \& Alshuaibi, A. (2012). The Effect of HR Practices, Leadership Style on Cyberdeviance: The Mediating Role of Organizational Commitment. Journal of Marketing and Management, $3(1), 22-48$.

Shirkhan, S., \& Nazari, R. (2014). An Examination of the Effect Talent Manage-ment on Organizational Entrepreneurship, a Case Study: Oil Products Company of Province of ILam in Iran. Kuwait Chapter of Arabian Journal of Business and Management Review, 3(12). https://doi.org/10.12816/0018840

Sloan, E., Hazucha, J., \& VanKatwyk, P. (2003). Strategic management of global leadership talent. Advances in 
Globl Leadership, 3, 235-274. https://doi.org/10.1016/S1535-1203(02)03013-7

Spector, P. E., \& Fox, S. (2005). A model of counterproductive work behavior. In S. Fox, \& P. E. Spector (Eds.), Counterproductive workplace behavior: Investigations of actors and targets (pp. 151-174). https://doi.org/10.1037/10893-007

Stevens, R. H. (2010). Managing Human Capital: How to Use Knowledge Management to Transfer Knowledge in Today‘s Multi-Generational Workforce. Int. Bus. Res., 3(3), 77-83. https://doi.org/10.5539/ibr.v3n3p77

Tiwari, U., \& Shrivastava, D. (2013). Strategies and practices of talent management and their impact on employee retention and effectiveness. The International Journal of Management, 2(4).

Uren, L., \& Samuel, J. (2007). From talent compliance to talent commitment. Strategic HR Review, 6(3), 32-35. https://doi.org/10.1108/14754390780000970

Van, Z. E., Mathafena, R. B., \& Ras, J. (2017). The development of a talent management framework for the private sector. SA Journal of Human Resource Management, $15,820$. https://doi.org/10.4102/sajhrm.v15i0.820

Vardi, Y., \& Wiener, Y. (1996). Misbehavior in organizations: a motivational frame-work, department of management and labor relations, college of business ad-ministration, cleveland state university. Organization Science, 7(2), 155. https://doi.org/10.1287/orsc.7.2.151

Yarnall, J. (2011). Maximizing the effectiveness of talent pools: a review of case study literature. Leadership and Organization Development Journal, 32(5), 510-526. https://doi.org/10.1108/01437731111146596

Yllner, E. (2013). Talent Management-Retaining and managing technical specialists in a technical career, Unpublished Master Thesis.

Zhang, S., \& David, B. D. (2012). Talent definition and talent management recognition in Chinese privateowned enterprises. Journal of Chinese Entrepreneurship, 4(2). https://doi.org/10.1108/17561391211242753

\section{Copyrights}

Copyright for this article is retained by the author(s), with first publication rights granted to the journal.

This is an open-access article distributed under the terms and conditions of the Creative Commons Attribution license (http://creativecommons.org/licenses/by/4.0/). 